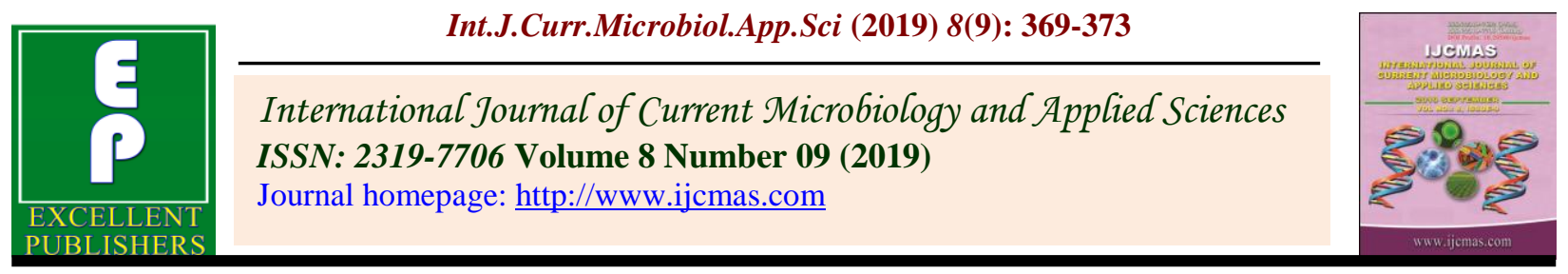

Original Research Article

https://doi.org/10.20546/ijcmas.2019.809.044

\title{
Field Evaluation of Backcross Progenies of Improved Samba Mahsuri Possessing SCM2 Gene
}

\author{
P. Jayamma ${ }^{1,2}$, C.H. Anuradha ${ }^{1}$, P. Senguttuvel ${ }^{2}$, E. Punniakotti ${ }^{2}$, M.B.V.N. Kousik ${ }^{2}$, \\ G. Harika ${ }^{2}$, K. Chaitra ${ }^{2}$, T. Ramesh ${ }^{1}$, D. Subramanyam ${ }^{2}$ and R.M. Sundaram²* \\ ${ }^{1}$ Institute of Biotechnology, Professor Jayashankar Telangana State Agricultural University \\ (PJTSAU), Rajendranagar, Hyderabad 500030, India \\ ${ }^{2}$ Indian Council of Agricultural Research (ICAR)-Indian Institute of Rice Research (IIRR), \\ Rajendranagar, Hyderabad 500030, India \\ *Corresponding author
}

\section{A B S T R A C T}

\begin{tabular}{|c|}
\hline Keywords \\
\hline $\begin{array}{l}\text { Back cross } \\
\text { introgression lines, } \\
\text { Improved Samaba } \\
\text { Mashuri, SCM2, } \\
\text { Gene specific and } \\
\text { allele specific } \\
\text { marker, } \\
\text { Codominant } \\
\text { marker, Culm } \\
\text { diameter, } \\
\text { Millimeters and } \mu \mathrm{m}\end{array}$ \\
\hline Article Info \\
\hline $\begin{array}{l}\text { Accepted: } \\
04 \text { August } 2019 \\
\text { Available Online: } \\
\text { 10 September } 2019\end{array}$ \\
\hline
\end{tabular}

\section{Introduction}

Rapid population growth and global demand for rice consumption has been estimated to rise from the present level of 700 million tons (mt) to $852 \mathrm{mt}$ in 2035. In the case of India, where 'rice is life' and where population is steadily increasing, we need to increase rice production from the present level of $103 \mathrm{mt}$ to at least $136 \mathrm{mt}$ by the year 2050
India ranks second in production of rice (Oryza sativa). The culm plays an important role in determining the lodging resistance and crop architecture of rice. The gene, STRONG CULM (SCM2) has been reported to be associated with strong culm. In the present study, $\mathrm{BC}_{2} \mathrm{~F}_{2}$ lines in the background of Improved Samba Mahsuri (ISM) derived by crossing Improved Samba Mahsuri (ISM) and a breeding line of Swarna possessing SCM2 were genotyped for presence of SCM2 with a newly designed gene specific marker (SCM2-8F/8R) and plants positive for the gene were then phenotyped and measured for Culm thickness with an average of three plants per each line of the $\mathrm{BC}_{2} \mathrm{~F}_{2}$ selected best lines along with the parents for culm thickness by measuring the Culm diameter with Vernier Calipers and by observing the Internode Culm cross sections under Microscope. All the backcross plants possessing the gene had significantly better culm thickness, and culm diameter as compared to Improved Samba Mahsuri indicating a perfect cosegregation of trait phenotype with marker genotype, validating the utility of the marker. The backcross plants of ISM possessing increased culm strength are being crossed with breeding lines of ISM possessing higher number of per panicle. 
from irrigated rice to meet the demand of the growing population. An increase in yield potential of rice was achieved in the 1960s through the development of semi-dwarf varieties possessing the sd1 gene like IR 8, Jaya etc. However, it is becoming increasingly harder to break yield ceiling by using conventional breeding and selection strategies (Peng et al., 1999). As a result, yield stagnation of newly developed rice varieties has been observed in the tropics.

The culm is one of the most important agronomic traits and plays a critical role in determining the lodging resistance and final architecture of crop plants, particularly in high-yielding rice varieties with heavy panicles. Because lodging resistance is one of the major targets in plant breeding and the length, strength and diameter of the culm are regarded as major factors that affect this trait, many efforts have been made to identify genes or quantitative trait loci (QTLs). A QTL controlling the trait strong culm, named SCM2 has been identified (Ookawa et al., 2010). Positional cloning of the gene underlying the QTL revealed that $S C M 2$ was identical to ABERRANT PANICLE ORGANIZATION1 (APO1), a gene previously reported to control panicle structure. SCM2 or APO1 located on Chromosome 6, the candidate gene for SCM2 encodes F-box-containing protein. Kim et al., (2016) sequenced SCM2-Habataki allele by using whole genome resequencing approach and identified donors effective for breeding high yielding varieties. In this study we have evaluated the SCM2 introgression line and report that SCM2 introgression lines possessed higher culm diameter, increased grain number and yield.

\section{Materials and Methods}

\section{Plant materials}

In the present study we have used Improved Samba Mahsuri (ISM) as the recurrent parent.
ISM is a high yielding, fine-grain type, popular rice variety essentially derived from the Indian mega-rice variety, Samba Mahsuri. ISM was developed from the cross BPT5204 $\times \quad 3 / \mathrm{SS} 113$ by ICAR-(ICAR-IIRR), Hyderabad, India in collaboration with CSIR(CSIR-CCMB), Hyderabad, India (Sundaram et al., 2008). It was released as a bacterial blight disease resistant variety by introgressing the major resistance genes, $X a 21, x a 13$ and $x a 5$ through marker-assisted backcross breeding (MABB; Sundaram et al., 2008). ISM has poor culm strength. A breeding line of Swarna (YPK-267) derived from the cross Swarna $\times$ Habataki possessing dark green foliage, semi-dwarf plant type, strong culm, high grain number was used as the donor parent to transfer of the gene encoding strong culm, SCM2.

\section{Marker-assisted introgression of SCM2 gene into Improved Samba Mahsuri (ISM)}

ISM was used as the recurrent parent and YPK-267 was used as the donor parent in a marker-assisted backcross breeding program. A newly designed marker named, RMS SCM2 8F/8R (Sundaram RM, unpublished), specific for the $S C M 2$ gene, was used to analyzed the $\mathrm{BC}_{1} \mathrm{~F}_{1} \mathrm{~s}, \mathrm{BC}_{2} \mathrm{~F}_{2 \mathrm{~s}}$ and $\mathrm{BC}_{2} \mathrm{~F}_{2}$ lines for presence of the gene. ISM was crossed with YPK-267 and the $\mathrm{F}_{1} \mathrm{~s}$ obtained from this cross were checked for heterozygozity using the Xa21 gene-specific, co-dominant marker, pTA248 (Ronald et al., 1992). The true $\mathrm{F}_{1} \mathrm{~s}$ were then crossed with ISM to generate $\mathrm{BC}_{1} \mathrm{~F}_{1} \mathrm{~s}$, which were then screened with the markers, pTA248, xa13-prom, xa5-FM, which are specific for Xa21 (Ronald et al., 1992), xa13 (Hajira et al., 2016) and xa5 (Hajira et al., 2016) to identify plants those which are homozygous for all the three bacterial blight resistance genes. Such $\mathrm{BC}_{1} \mathrm{~F}_{1}$ plants were screened for the presence of SCM2 using the gene-specific marker, RMS SCM2-8F/8R (Sundaram RM, unpublished) and a single such plant possessing the gene in heterozygous condition and also 
phenotypically similar to ISM was then backcrossed with Improved Samba Mahsuri to generate $\mathrm{BC}_{2} \mathrm{~F}_{1} \mathrm{~s}$. The $\mathrm{BC}_{2} \mathrm{~F}_{1}$ plants were then screened with RMS SCM2-8F/8R marker to identify the plants positive for the gene and a single plant, possessing the gene and also closely resembling ISM was then selfed to generate $\mathrm{BC}_{2} \mathrm{~F}_{2} \mathrm{~S}$, which were then screened with SCM2-8F/8R marker to identify homozygous plants. For further advancement of the selected $\mathrm{BC}_{2} \mathrm{~F}_{2} \mathrm{~S}$ were then phenotyped with five selected $\mathrm{BC}_{2} \mathrm{~F}_{2}$ lines were evaluated for their culm thickness under field condition.

\section{Phenotypic evaluation of the backcross} derived lines of ISM for strong culm

A total of five introgression lines parents (at $\mathrm{BC}_{2} \mathrm{~F}_{2}$ generation) were phenotyped along with the donor and recurrent parents for culm thickness and culm strength in field conditions in wet season 2018. The experiments were conducted using randomized block design in two replications in the experimental farms of ICAR-Indian Institute of Rice Research (ICAR-IIRR), Rajendranagar, Hyderabad, India and phenotypic readings were recorded in the laboratory of the Department of Crop Physiology, College of Agriculture, Professor Jaya Shankar Telangana State Agricultural University (PJTSAU), Rajendranagar, Hyderabad, India. The observations were taken at full ripening stage of rice as described earlier (Anand Rao et al., 2017). Stem outer diameter was measured at four internodes of the plant in field after stripping off leaves and leaf sheaths, by using digital Vernier caliper and readings were recorded and expressed in $\mathrm{mm}$. And cross sections of stem were observed under Microscope in CIC (Central Instrumentation Cell), PJTSAU, and Hyderabad, India.

\section{Results and Discussion}

In the present study the $\mathrm{BC}_{2} \mathrm{~F}_{2}$ lines developed from the cross ISM and Swarna breeding line
(YPK-267) were confirmed for presence of SCM2 through marker analysis and five selected lines (YGR-222, YGR-40, YGR-230, YGR-56, YGR-281 and YGR-258) and parents were phenotyped for culm thickness. All the lines showed increased culm thickness and enhanced culm strength by increasing culm diameter (Table 1). We measured the culm thickness for four different internodes i.e. basal internode, first internode, second internode and third internodes in five selected $\mathrm{BC}_{2} \mathrm{~F}_{2}$ lines and compared with parents at full ripening stage using Vernier calipers expressed in Millimeters. And also we observed the stem internode cross sections under Microscope for observing the culm diameter expressed in $\mathrm{mm}$. The data was collected for selected for five lines, with five plants for each line. The culm thickness ranged from 3.6 to $6.0 \mathrm{~mm}$. All selected lines internode culm diameters ranged from 4.3 to $5.4 \mathrm{~mm}$ at the basal internode, 4.1 to $5.8 \mathrm{~mm}$ at the first internode, 3.2 to $3.8 \mathrm{~mm}$ at the second internode and 1.9 to $2.8 \mathrm{~mm}$ at the third internode. These selected lines were observed to significantly better in culm thickness as compared to the recurrent parent ISM (3.674 $\mathrm{mm}$ ) and equivalent to the donor parent (5.4 $\mathrm{mm})$. Two lines ISM-YGR-222 and ISMYGR-230 at first internode were found to possess considerably thick culm 6.05 and 5.95 $\mathrm{mm}$ respectively among all pyramided lines. The selected SCM2 pyramided lines were found to perform equivalent to or better than ISM in terms of number of productive tillers per plant, panicle length and high grain number (Table 1). Observations of culm cross sections were recorded from the first internode region, and the improved lines had values ranging from 19.5 to $28.8 \mathrm{~mm}$ as compared to the recurrent parent, ISM $(12.457 \mathrm{~mm})$. These observations indicate that the improved breeding lines of ISM have better culm dimensions due to the presence of SCM2.

The culm is one of the most important agronomic traits and plays a critical role in 
determining the lodging resistance and final architecture of crop plants. Because lodging resistance is one of the major targets in plant breeding and the strength and diameter of the culm are regarded as major factors that affect this trait, many efforts have been made to identify genes or quantitative trait loci (QTLs). For instance, Rashid et al., (2016) studied haplotypic SNP positional variations and identified superior alleles using diverse genotype population. An indica variety, Habataki, which was reported to have stiff culm and high grain number, had a favorable allele for the gene, SCM2 (Adachi et al., 2010).

Table.1 Culm diameter of the $\mathrm{BC}_{2} \mathrm{~F}_{2}$ introgression lines in the genetic background of ISM carrying SCM2 gene

\begin{tabular}{|l|l|}
\hline Genotype/ Name of the line & Culm diameter $(\mathbf{m m})$ \\
\hline ISM (recipient parent) & 15.85869 \\
\hline YPK-267 (donor parent) & 28.63076 \\
\hline YGR-222 & 28.85806 \\
\hline YGR-40 & 21.48696 \\
\hline YGR-230 & 19.50095 \\
\hline YGR-56 & 22.0942 \\
\hline YGR-281 & 24.28644 \\
\hline YGR-258 & 24.97990 \\
\hline
\end{tabular}

We attempted the present experiment to transfer the gene into an elite rice variety, Improved Samba Mahsuri, which has a weak culm through this study have developed and identified a set of promising $\mathrm{BC}_{2} \mathrm{~F}_{2}$ lines carrying $S C M 2$ gene. The backcross derived lines of ISM possessing SCM2 had significantly enhanced culm strength, indicating that $S C M 2$ gene conferred positive role in enhancing culm strength. We are in the process of developing and identifying lines which not only possess strong culm but also higher number of grains per panicle (and higher yield) by crossing some of the promising line identified in this study (YGR222) with breeding lines of Improved Samba Mahsuri possessing Gnla (gene associated with increased grain number; Ashikari et al., 2005) and/or OsSPL14 (gene associated with increasing grain number and improvement in panicle architecture) to enhance the yield potential of ISM.

\section{Acknowledgements}

The authors thank the Director, ICAR-Indian Institute of Rice Research, for providing all the necessary facilities and we are thankful to the corresponding author and Yield group members were provided tough review of the MS.

\section{References}

Adachi S, Tsuru Y, Kondo M, Yamamoto T, Arai-Sanoh Y, Ando T, Ookawa T, Yano M, Hirasawa T. 2010. Characterization of a rice variety with high hydraulic conductance and identification of the chromosome region responsible using chromosome segment substitution lines. Annals of Botany 106(5): 803-811.

Ashikari M, Sakakibara H, Lin S, Yamamoto T, Takashi T, Nishimura A, Angeles 
ER, Qian Q, Kitano H, and Matsuoka M. 2005. Cytokinin oxidase regulates rice grain production. Science 309: 741745.

Hajira SK, Sundaram RM, Laha GS, Yugander A, Balachandran SM, Viraktamath BC, Rekha G. 2016. A Single-Tube, functional marker-based multiplex PCR assay for simultaneous detection of major bacterial blight resistance genes $\mathrm{Xa21}, \mathrm{xa13}$ and $x a 5$ in Rice. Rice Science 23(3):144-151.

http://www.icariirr.org/IIRR\%20Vision\%202050.pdf

Kim S-R, Ramos J, Ashikari M, Virk PS, Torres EA, Nissila E, Jena KK. 2016. Development and validation of allele-specific SNP/indel markers for eight yield-enhancing genes using whole-genome sequencing strategy to increase yield potential of rice, Oryza sativa $\mathrm{L}$. Rice 9:1.

Ookawa T, Hobo T, Yano M, Murata K, Ando T, Miura H, Asano K, Ochiai Y, Ikeda M, Nishitani R, Ebitani T, Ozaki $\mathrm{H}$, Angeles ER, Hirasawa T, Matsuoka M. 2010. New approach for rice improvement using a pleiotropic QTL gene for lodging resistance and yield. Nature Communications 1:132.

Peng S, Cassman KG, Virmani SS, Sheehy J, Khush GS. 1999. Yield potential trends of tropical rice since the release of IR8 and the challenge of increasing rice yield potential. Crop Science 39: 15521559.

Rao AN, Sreekanth B, Madhav SM, Reddy NS. 2017. Studies on physical and mechanical properties of rice stem for lodging tolerance at reproductive phase in rice (Oryza sativa L.). International Journal of Pure \& Applied Bioscience 5(3): 407-414

Rashid MA, Zhao Y, Zhang H, Li J, Li Z. 2016. Nucleotide diversity, natural variation, and evolution of Flexible culm-1 and Strong culm-2 lodging resistance genes in rice. Genome 59(7): 473-483.

Ronald P.C, Albano, B. Tabien, R. Abenes, L. Wu K.S, McCouch SR and Tanksley S.D. 1992. Genetic and physical analysis of the rice bacterial blight disease resistance locus Xa21. Molecular and General Genetics 236: 113-120.

Sundaram RM, Vishnupriya MR, Biradar SK, Laha GS, Reddy GA, Shoba Rani N, Sarma NS, Sonti RV. 2008. Marker assisted introgression of bacterial blight resistance in Samba Mahsuri, an elite indica rice variety. Euphytica 160:411422.

\section{How to cite this article:}

Jayamma, P., C.H. Anuradha, P. Senguttuvel, E. Punniakotti, M.B.V.N. Kousik, G. Harika, K.Chaitra, T. Ramesh, D. Subramanyam and Sundaram, R.M. 2019. Field Evaluation of Backcross Progenies of Improved Samba Mahsuri Possessing SCM2 Gene. Int.J.Curr.Microbiol.App.Sci. 8(09): 369-373. doi: https://doi.org/10.20546/ijcmas.2019.809.044 